Iranian (Iranica) Journal of Energy \& Environment Journal Homepage: www.ijee.net

IJEE an official peer review journal of Babol Noshirvani University of Technology, ISSN:2079-2115

\title{
Extraction, Characterization and Identification of Major Chemical Components of Areca Nut Extract at its Different Stages
}

\author{
K. Sumalatha, J. Ishwara Bhat* \\ Department of Chemistry, Mangalore University, Mangalagangothri, India
}

\section{PAPER I NFO}

\section{Paper history:}

Received 05 Januay 2019

Accepted in revised form 24 June 2019

\section{Keywords:}

Areca Nut

Anti-bacterial

Anti-oxidant

Crystalline Compounds

Phytochemicals

\begin{abstract}
$A B S T R$ R A C T
The medicinal properties shown by different plants are due to phytochemicals present in the plant. These phytochemicals are the most vital source for the treatment of various diseases. Different phytochemicals have an extensive range of activities, which help to enhance the immune system and give resistance to the body to protect against attack of harmful pathogens. It is well accepted fact that even areca plant seed is also a good source of phytochemicals and hence planned to examine the phytochemicals present in its different stages, that is, tender areca nut (TACN), mature areca nut (MACN) and dry areca nut (DACN). All the three stages of areca nut extract were examined for tannin, phenols, flavonoids, alcohols, acids, amines and nitro groups. They showed positive results for all the tests. Trace elements such as $\mathrm{Cu}, \mathrm{Fe}, \mathrm{Zn}, \mathrm{Cr}, \mathrm{Ni}, \mathrm{Pb}$ are present in small amount when compared to $\mathrm{Na}$ and $\mathrm{K}$, and are identified by Atomic Adsorption Spectroscopy. FTIR analysis revealed the presence of functional groups such as $-\mathrm{OH}$. $-\mathrm{NH},-\mathrm{CH},>\mathrm{C}=\mathrm{O},>\mathrm{C}=\mathrm{C}<,>\mathrm{C}-\mathrm{O}-\mathrm{C}$ and $-\mathrm{NO}$ groups in the areca nut extract. Extracts were investigated through GC-MS for identification of the chemical composition of extract, on comparison with results obtained from FTIR, and molecular mass nine, fourteen and five compounds were identified in TACN, MACN and DACN extracts, respectively.
\end{abstract}

doi: $10.5829 /$ ijee.2019.10.02.11

\section{INTRODUCTION}

Areca palm (Arecacatechu L.) is widely cultivated in several South Asian and Southeast Asian countries including India, China, Bangladesh, Indonesia, Myanmar, Thailand, Malaysia, Vietnam, Philippines etc. Its fruit or seed is called areca nut or betel nut. It has characteristic astringent and slightly bitter in taste [1]. The major phytochemical constituents of areca nut are polyphenols, including flavonoids and tannins (up to $29.8 \%$ ), polysaccharides (up to $25.7 \%$ ), proteins (up to $9.4 \%$ ), fats (up to $15.1 \%$ ), fibers (up to $15.4 \%$ ), alkaloids (up to .24\%) and minerals (up to $2.5 \%$ ) [2]. the medicinal uses and properties of areca nut were investigated. It has anti-oxidant [3], anti-inflammatory and analgesic [4], anti-diabetic [5], hypolipidemic [6], antimalaria [7], anti-aging [8], anti-ulcer [9], anti-migraine [10], anti-hypertensive [11], anti-depressant [12], anti-allergic [13], anthelmintic [14], hepatoprotective [15], anti-tumor activities [16].

\section{MATERIALS AND METHODS}

\section{Collection of the sample}

Areca nut samples of different stages (tender, mature and dry areca nuts) were collected form the areca nut palm from nearby village. It was washed with water, dried and covered in a polythene bag.

\section{Preparation of the extract}

Husk of the areca nuts were removed, chopped into small pieces, washed with distilled water and then dried in a hot air oven at $40^{\circ} \mathrm{C}$ for an hour, after drying it was powdered using mechanical crusher. Powder was extracted with methanol in a soxhlet extraction apparatus for 4 hours. After the completion of the extraction process, extract of tender areca $(\mathrm{TACN})$, mature areca $(\mathrm{MACN})$ and dry areca $(\mathrm{DACN})$ were separately filtrated with whatmann filter paper and the filtrate was dried at room temperature till a powder was formed and then which was kept in a desiccator.

\section{Characterization of the extract}

Analysis of areca nut extracts for the presence of phytochemicals The methanolic extract of different stages of Areca nut were subjected to qualitative chemical screening for the identification of various classes of active chemical constituents present in the extracts.

Atomic absorption spectroscopy $0.2 \mathrm{~g}$ of sample was digested with $2 \mathrm{ml}$ of concentrated $\mathrm{H}_{2} \mathrm{SO}_{4}$ and $1 \mathrm{ml} 30 \% \mathrm{H}_{2} \mathrm{O}_{2}$ at $200^{\circ} \mathrm{C}$ on a hot plate for $30 \mathrm{~min}$. The mixture was cooled to 
room temperature and was again digested at $250^{\circ} \mathrm{C}$ in the presence of $1 \mathrm{ml} 30 \% \mathrm{H}_{2} \mathrm{O}_{2}$ till a clear brown colour solution was obtained. Then the solution was diluted to $100 \mathrm{ml}$ using distilled water [17]. Elemental analysis was carried out by using GCB 932 plus Atomic adsorption spectroscopy.

X-ray diffraction (XRD) studies

X-ray diffraction analysis, of all the three extracts was carried out by powder $\mathrm{X}$-ray diffractometer method; for $2 \theta$ values $5^{0}-80^{\circ}$ at $40 \mathrm{kV}$ and $15 \mathrm{~mA}$ using $\operatorname{CuK} \alpha(\lambda=1.5418 \AA)$ radiation.

FTIR spectroscopic study Fourier Transformer Infrared Spectrometer (FTIR) is the most powerful tool for identifying the functional groups present in the compounds. Powder samples of three areca nuts were loaded separately in the FTIR Spectrometer (Perkin Elmer-Spectrum RX-IFTIR), with a scan range of 400-4000 $\mathrm{cm}^{-1}$ and resolution of $1 \mathrm{~cm}^{-1}$ to get the signal for the likely present functional groups.

Gas chromatography - mass spectroscopy (GC-MS analysis) The GC-MS analysis of bioactive compounds from the different extracts of the nuts of Areca catechu was done using Thermo Scientific TSQ-8000 GC-MS Technique. Mass spectrometer comes paired with the TRACE 1300 GC along with auto sampler for automated sample handling. Temperature program (oven temperature) was $40^{\circ} \mathrm{C}$ raised to $290^{\circ} \mathrm{C}$ at a rate of $5^{\circ} \mathrm{C} / \mathrm{min}$ and injection volume was $1.0 \mu \mathrm{l}$ with the scan range of $50-700 \mathrm{~m} / \mathrm{z}$. TotalGC running time was $30.11,30.10$ and 29.09 minutes for tender, mature and dry areca nut extracts, respectively. The results were compared with NIST library search program, to get the idea of the chemical component present in the extracts.

\section{Thermo gravimetric (TGA/ DTA) analysis}

Thermal stability of different stages of areca nut was studied by Thermogravimetric analyzer SDT Q600 V20.9 (Japan). This measures the weight loss of the sample in relation with the temperature, heat flow, derivative weight and temperature difference, and there by it measures TGA, DSC, DTG and DTA, respectively. Nitrogen flow $100 \mathrm{ml} / \mathrm{min}$, scan rate is $20^{\circ} \mathrm{C} / \mathrm{min}$ along with scan temperature range $20^{\circ} \mathrm{C}$ to $900^{\circ} \mathrm{C}$ was maintained in the instrument.

\section{RESULT AND DISCUSSION}

\section{Phytochemical analysis of extracts of areca nut}

Phytochemical analysis done as per normal procedure, methanolic extract of different stages of Areca nut extracts clearly revealed the presence of phenols, tannins, alcohols, flavonoids, acids, amines and nitro group by answering the respective tests.

\footnotetext{
Atomic absorption spectroscopy

Elemental analysis of three extracts indicated the quantity of trace elements present in the extract. Copper $(\mathrm{Cu})$, Iron $(\mathrm{Fe})$, Zinc (Zn), Nickel (Ni), Sodium (Na) and Potassium (K) are present in areca nut. $\mathrm{Cu}$ concentration found to be decreases with maturation. Amount of $\mathrm{Fe}, \mathrm{Zn}$ and $\mathrm{Cr}$ is high in dried areca extract compared with other two areca nut extract. Concentration of $\mathrm{Ni}, \mathrm{Pb}$ and $\mathrm{Na}$ remained constant in tender and dry areca nut was as amount of $\mathrm{K}$ decreased in the order
}

of TACN $>$ DACN $>$ MACN. Majority of the trace element was found more in DACN extract, this is due to the dehydration of water on drying undersun light, which probably increased the concentration of Trace element present in dry areca nut [18-21].

\section{Xrd analysis}

Powder X-ray diffraction pattern shows both sharp and broad peaks. The sharp peaks are due to the crystalline components and broad peaks are due to the powder components present in the mixture of the samples. XRD spectra obtained (Figure 1) is slightly matching with the AAS data shown in Table 1. Small distraction noticed in comparison with AAS data may be due to the presence of lighter elements $\mathrm{Na}$ and $\mathrm{K}$. The expected Crystallinity should be in the increasing order of DACN > TACN > MACN but the XRD pattern showed the variation in the order of DACN > MACN > TACN. Higher Crystallinity index describe the higher crystal nature or molecular alignment in the sample. Crystallinity index is calculated by using the formula:

$$
C r I=\frac{I_{c r y}-I_{a m p}}{I_{c r y}} \times 100
$$

where, $\mathrm{I}_{\text {cry }}$ and $\mathrm{I}_{\mathrm{amp}}$ is intensity of crystalline and amorphous peaks respectively. Amorphous peak region $2 \theta=18^{0}$ [22-24]. All the three extracts are expected to possess various elements (AAS) in the extract, but which are of different size or radius. So they do not form any proper crystal and hence there will be much lattice strain and dislocation density, which probably lead to form various hkl values to X-ray and hence blurred or not well defined $\mathrm{x}$-ray spectra is obtained. Therefore, crystallite size decreases with increase in lattice strain and dislocation density [25, 26].

\section{FTIR spectroscopy}

TACN, MACN and DACN showed positive results for phenols, tannins, flavonoids, alcohols, carboxylic acids, amines and nitrates. These are confirmed by FTIR study, which predict the presence of functional groups such as $-\mathrm{OH}$, $-\mathrm{CH}, \quad-\mathrm{C}=\mathrm{O}, \quad-\mathrm{NO}, \quad-\mathrm{C}-\mathrm{O}-\mathrm{C}$ stretching. - $\mathrm{NH}$ (bending vibrations are observed), $-\mathrm{C}=\mathrm{C}$ stretch is due to the presence of aromatic compounds [27, 28].

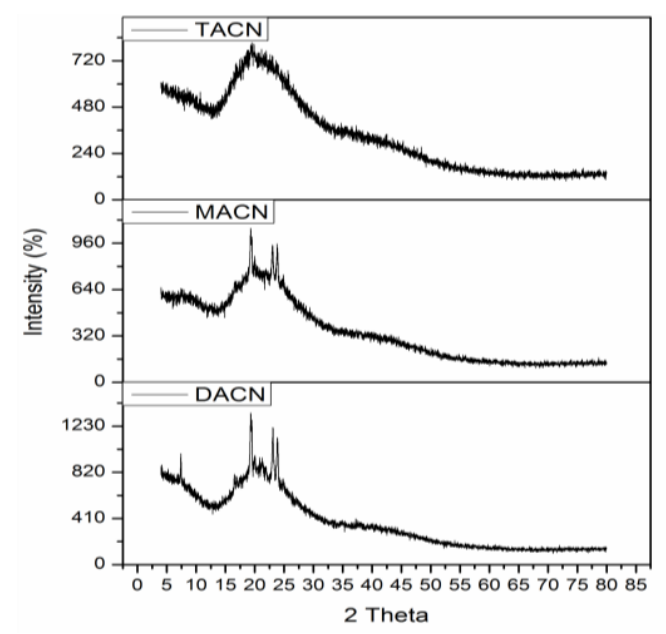

Figure 1. XRD spectrum of TACN, MACN and DACN extract 
TABLE 1. Result obtained from Atomic Adsorption Spectroscopy

\begin{tabular}{|c|c|c|c|c|c|c|c|c|}
\hline \multirow{2}{*}{ Elements } & $\mathbf{C u}$ & $\mathbf{F e}$ & $\mathbf{Z n}$ & $\mathrm{Cr}$ & $\mathbf{N i}$ & $\mathbf{P b}$ & $\mathbf{N a}$ & $\mathbf{K}$ \\
\hline & \multicolumn{6}{|c|}{$\mu \mathrm{g} / \mathrm{ml}$} & \multicolumn{2}{|c|}{$\mathrm{mg} / \mathrm{ml}$} \\
\hline Tender Areca nut & 0.0375 & 0.394 & 0.0823 & 0.0523 & 0.2304 & 0.2755 & 2.6 & 14.2 \\
\hline Mature Areca nut & 0.024 & 0.1528 & 0.0826 & 0.0648 & 0.1686 & 0.2888 & 1 & 6 \\
\hline Dry Areca nut & 0.0116 & 1.1185 & 0.3766 & 0.1640 & 0.2130 & 0.2934 & 2 & 10 \\
\hline
\end{tabular}

TABLE 2. Data obtained from XRD analysis

\begin{tabular}{|c|c|c|c|c|c|c|}
\hline Sl. No. & Samples & $2 \theta$ (degrees) & $\mathbf{D}(\AA)$ & $\delta$ (dislocation density) & \& (lattice strain) & $\operatorname{CrI}(\%)$ \\
\hline \multirow{7}{*}{1} & \multirow{7}{*}{ TACN } & 17.33 & 0.04025 & 617.26 & 8.6171 & \multirow{7}{*}{13.79} \\
\hline & & 19.64 & 0.04039 & 612.98 & 8.5888 & \\
\hline & & 21.15 & 0.04048 & 610.26 & 8.5685 & \\
\hline & & 22.67 & 0.04058 & 607.26 & 8.5465 & \\
\hline & & 25.92 & 0.04083 & 599.84 & 8.4946 & \\
\hline & & 37.93 & 0.04208 & 564.73 & 8.2434 & \\
\hline & & 42.31 & 0.04267 & 549.23 & 8.1292 & \\
\hline \multirow{9}{*}{2} & \multirow{9}{*}{ MACN } & 12.72 & 0.04095 & 596.34 & 8.4695 & \multirow{9}{*}{28.03} \\
\hline & & 13.17 & 0.04097 & 595.76 & 8.4658 & \\
\hline & & 19.34 & 0.04129 & 586.56 & 8.4008 & \\
\hline & & 19.52 & 0.04130 & 586.27 & 8.3986 & \\
\hline & & 20.01 & 0.04133 & 585.45 & 8.3924 & \\
\hline & & 22.99 & 0.04154 & 579.52 & 8.3510 & \\
\hline & & 23.86 & 0.04161 & 577.57 & 8.3379 & \\
\hline & & 24.92 & 0.04168 & 575.63 & 8.3279 & \\
\hline & & 42.18 & 0.01362 & 525.57 & 7.9511 & \\
\hline \multirow{8}{*}{3} & \multirow{8}{*}{ DACN } & 7.40 & 0.03598 & 772.46 & 9.6414 & \multirow{8}{*}{47.48} \\
\hline & & 13.04 & 0.03614 & 765.64 & 9.5991 & \\
\hline & & 16.51 & 0.03628 & 759.74 & 9.5615 & \\
\hline & & 19.32 & 0.03642 & 753.91 & 9.5246 & \\
\hline & & 20.72 & 0.03650 & 750.61 & 9.5041 & \\
\hline & & 21.28 & 0.03653 & 749.38 & 9.4954 & \\
\hline & & 23.66 & 0.03668 & 743.26 & 9.4564 & \\
\hline & & 23.91 & 0.03670 & 742.45 & 9.4520 & \\
\hline
\end{tabular}

Gas chromatography - mass spectroscopy

Chemical species present in methanolic extracts of TACN, MACN and DACN were studied by GC-MS analysis. Species of various size and mass at different retention time was eluted during GC-MS analysis. The mass of those eluted samples were systematically determined by mass spectrometry attached to gas chromatography instrument. The instrumental data were supported by available library data. Hence occurrences of chemical species were identified from massspectrum at that respective retention time.

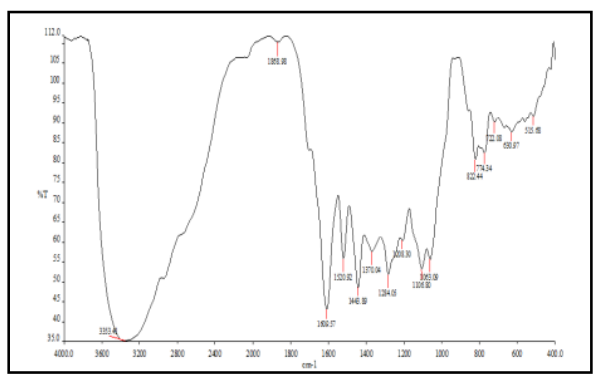

Figure 2. IR Spectrum of TACN extracts

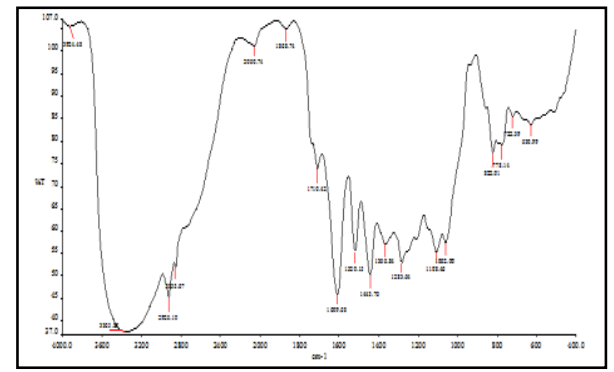

Figure 3. IR Spectrum of MACN extracts

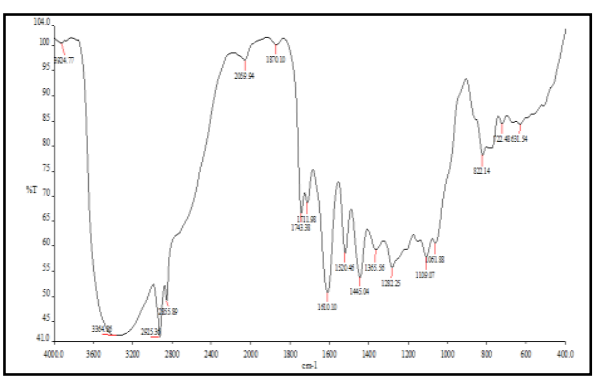

Figure 4. IR Spectrum of DACN extracts 
TABLE 3. Result obtained from FTIR spectrum

\begin{tabular}{|c|c|c|c|c|}
\hline \multirow{2}{*}{ Sl. No. } & TACN & MACN & DACN & \multirow{2}{*}{ Functional groups } \\
\hline & \multicolumn{3}{|c|}{ Wave numbers $\left(\mathrm{cm}^{-1}\right)$} & \\
\hline 1 & 3353.41 & 3365.8 & 3364.8 & -OH, -NH combined peak \\
\hline 2 & - & $2926.1 \& 2855.7$ & $2925.4 \& 2855.9$ & $-\mathrm{CH}$ stretch \\
\hline 3 & - & 1710.0 & $1743.4 \& 1710.0$ & $-\mathrm{C}=\mathrm{O}$ stretch \\
\hline 4 & $1609.6 \& 1443$ & $1609 \& 1443.9$ & $1610.1 \& 1445.0$ & $-\mathrm{C}=\mathrm{C}$ aromatic stretch \\
\hline 5 & $1520.9 \& 1370$ & $1520.2 \& 1366.8$ & $1520.5 \& 1365.5$ & -NO symmetric \& asymmetric stretch \\
\hline 6 & 1208.0 & $1106.0-1063.1$ & $1109.1-1061.9$ & $-\mathrm{C}-\mathrm{O}-\mathrm{C}$ stretch \\
\hline 7 & 822.4 & 822.07 & 822.1 & -NH bending vibrations \\
\hline 8 & - & 778 & - & $-\mathrm{C}-\mathrm{Cl}$ stretch \\
\hline
\end{tabular}

During the growth of areca nut from tender to mature the number of chemical species increases in it and as drying the number decreased probably due to drying in hot sun light for 48 days. Low melting point chemical species might evaporated.

When the sample subjected to GC-MS, different compounds have been eluted with different retention time and molecular formula. Literature survey propose some structure for molecular weight and molecular formula given, from this functional groups present in the structure was identified. FTIR spectra also showed same functional groups. By comparing these functional groups rough idea on nature of the compound present in the system was identified. This was made us to get clear idea about the compound present even though there are several compounds for a given retention time. Melting points was also identified from the literature survey for the same compounds, which was compared with different stages exhibited by samples with TGA and DTA graphs.

All these helped in proposing structure of most likely compound present in the extract. This has helped us in reducing the number of chemical species in case of TACN from 25 to 9, MACN 42 to 14 and DACN 15 to 5 species. Structure of these compounds along with molecular formula, molecular weight and melting and boiling points are given in the Tables 4-6.

TABLE 4. Phytochemicals identified from GC-MS analysis of TACN extract

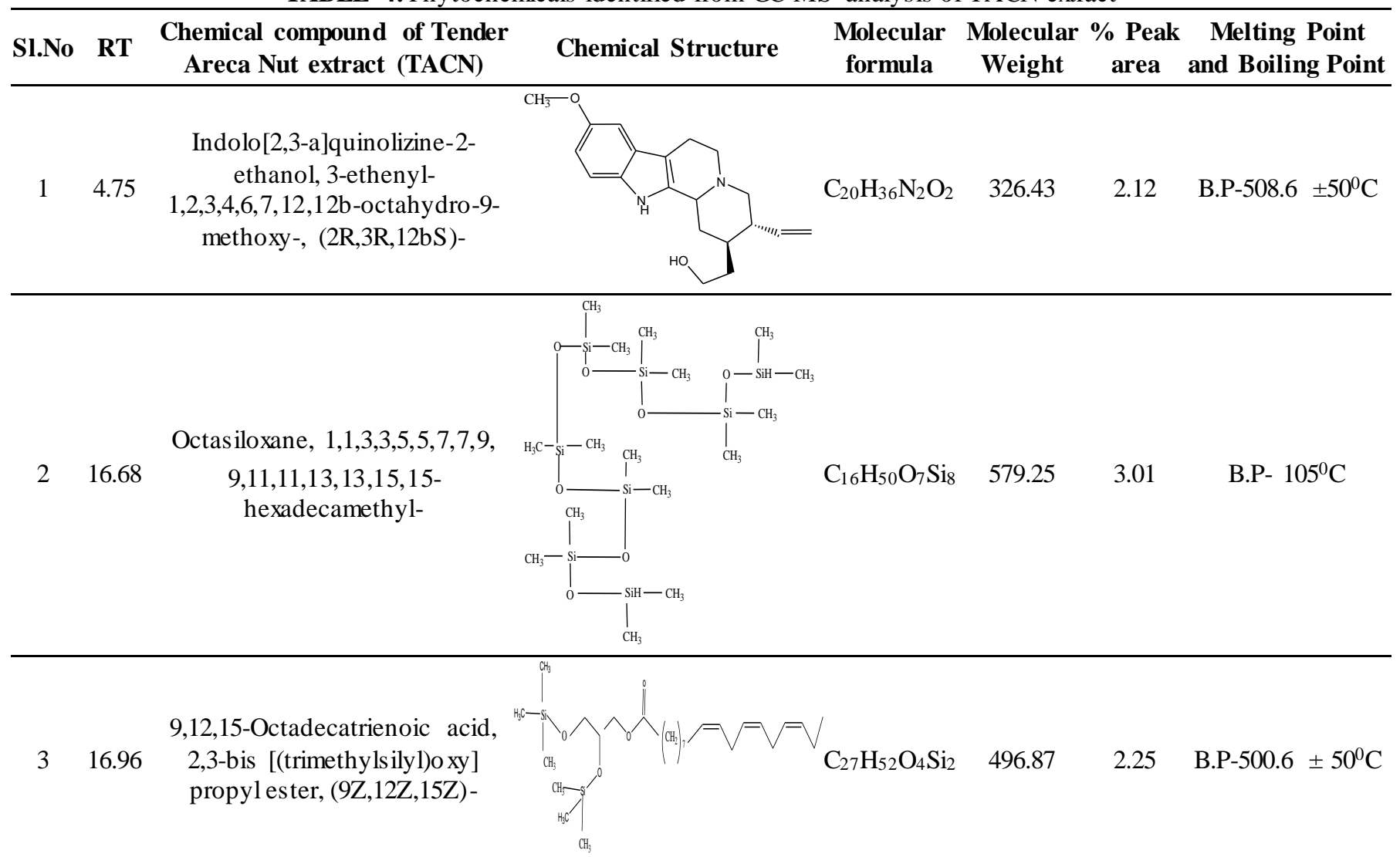




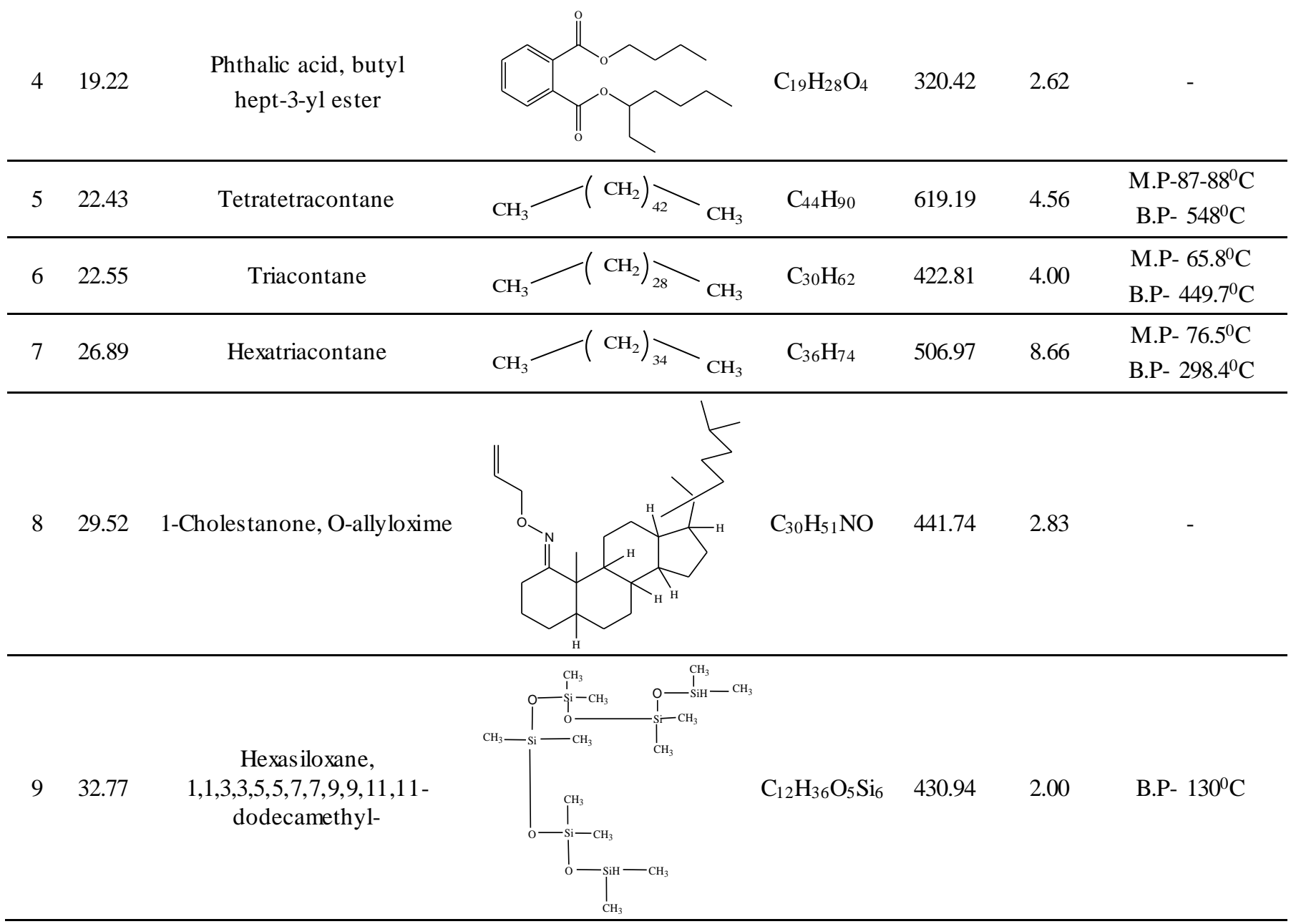

TABLE 5. Phytochemicals identified from GC-MS analys is of MACN extract

\begin{tabular}{|c|c|c|c|c|c|c|c|}
\hline Sl. No. & RT & $\begin{array}{l}\text { Chemical compound of } \\
\text { Mature Areca Nut extract } \\
\text { (MACN) }\end{array}$ & Chemical Structure & $\begin{array}{l}\text { Molecular } \\
\text { formula }\end{array}$ & $\begin{array}{l}\text { Molecular } \\
\text { Weight }\end{array}$ & $\begin{array}{c}\% \text { Peak } \\
\text { area }\end{array}$ & $\begin{array}{c}\text { Melting Point } \\
\text { and Boiling } \\
\text { Point }\end{array}$ \\
\hline 1 & 4.66 & $\begin{array}{c}\text { 2,7-Diphenyl 1-1,6- } \\
\text { dioxopyridazinol } \\
\text { [4,5:2',3’]pyrrolo [4',5'- } \\
\text { dipyridazine] }\end{array}$ & & $\mathrm{C}_{20} \mathrm{H}_{13} \mathrm{~N}_{5} \mathrm{O}_{2}$ & 355.31 & 1.97 & $\begin{array}{c}\text { B.P- } 662.5 \pm \\
65^{0} \mathrm{C}\end{array}$ \\
\hline 2 & 4.89 & $\begin{array}{l}\text { (22S)-21-Acetoxy -6à,11á- } \\
\text { dihydroxy-16à,17à- } \\
\text { propylm } \\
\text { ethylenedioxypregna-1,4- } \\
\text { diene-3,20-dione }\end{array}$ & & $\mathrm{C}_{27} \mathrm{H}_{36} \mathrm{O}_{8}$ & 488.57 & 0.48 & $\begin{array}{c}\text { B.P- } 650.3 \pm \\
55^{\circ} \mathrm{C}\end{array}$ \\
\hline 3 & 7.25 & $\begin{array}{c}\text { Cyclotetrasiloxane, } \\
\text { octamethyl- }\end{array}$ & & $\mathrm{C}_{8} \mathrm{H}_{24} \mathrm{O}_{4} \mathrm{Si}_{4}$ & 296.62 & 3.36 & $\begin{array}{l}\text { M.P- } 17.5^{0} \mathrm{C} \\
\text { B.P- } 175^{\circ} \mathrm{C}\end{array}$ \\
\hline 4 & 8.61 & $\begin{array}{c}\text { Bicyclo[4.1.0]hept-2-ene, } \\
\text { 4,7,7-trimethyl- }\end{array}$ & & $\mathrm{C}_{10} \mathrm{H}_{16}$ & 136.23 & 0.91 & $\begin{array}{l}\text { B.P- } 166.5- \\
167.0^{\circ} \mathrm{C}\end{array}$ \\
\hline
\end{tabular}




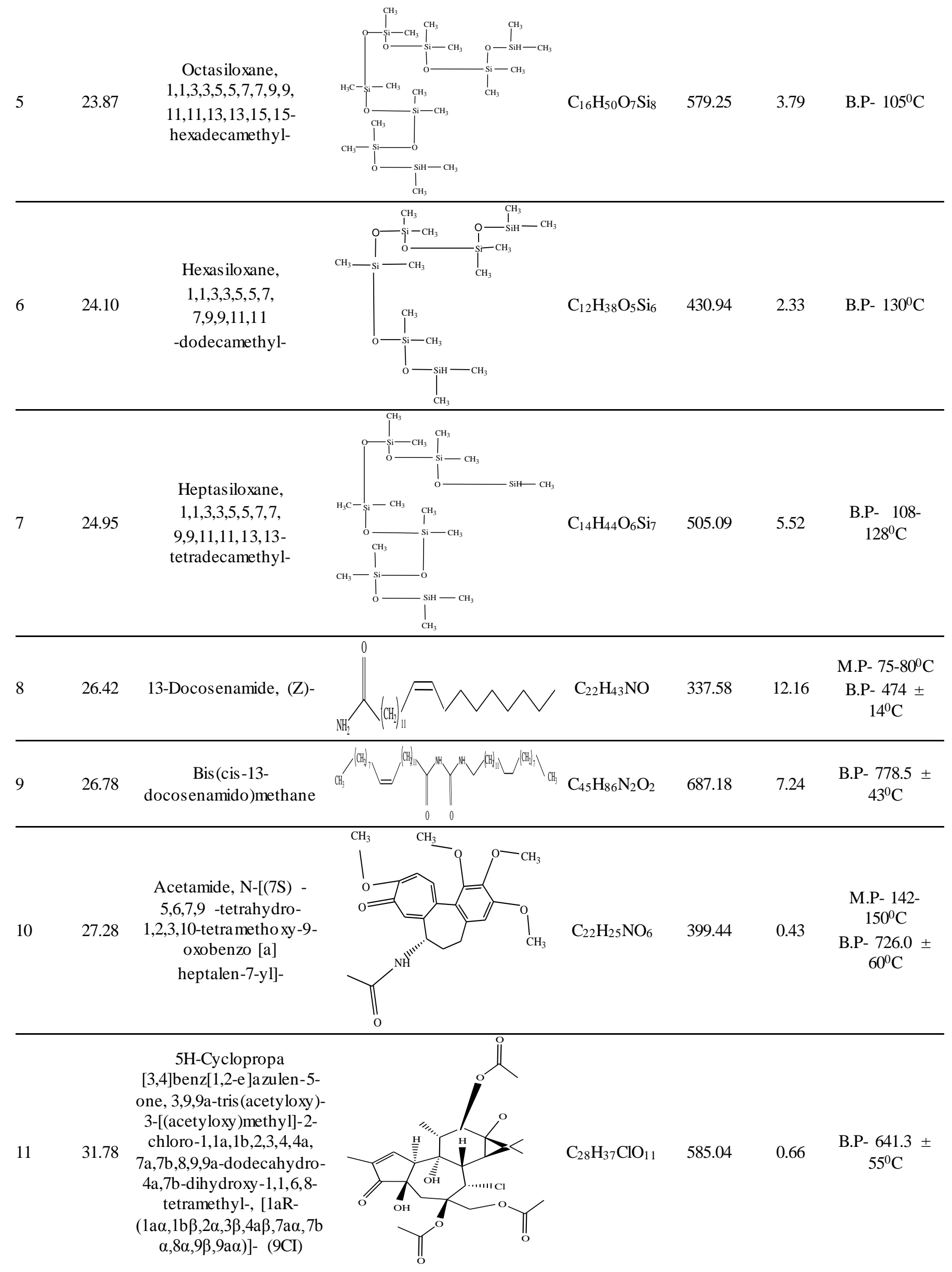




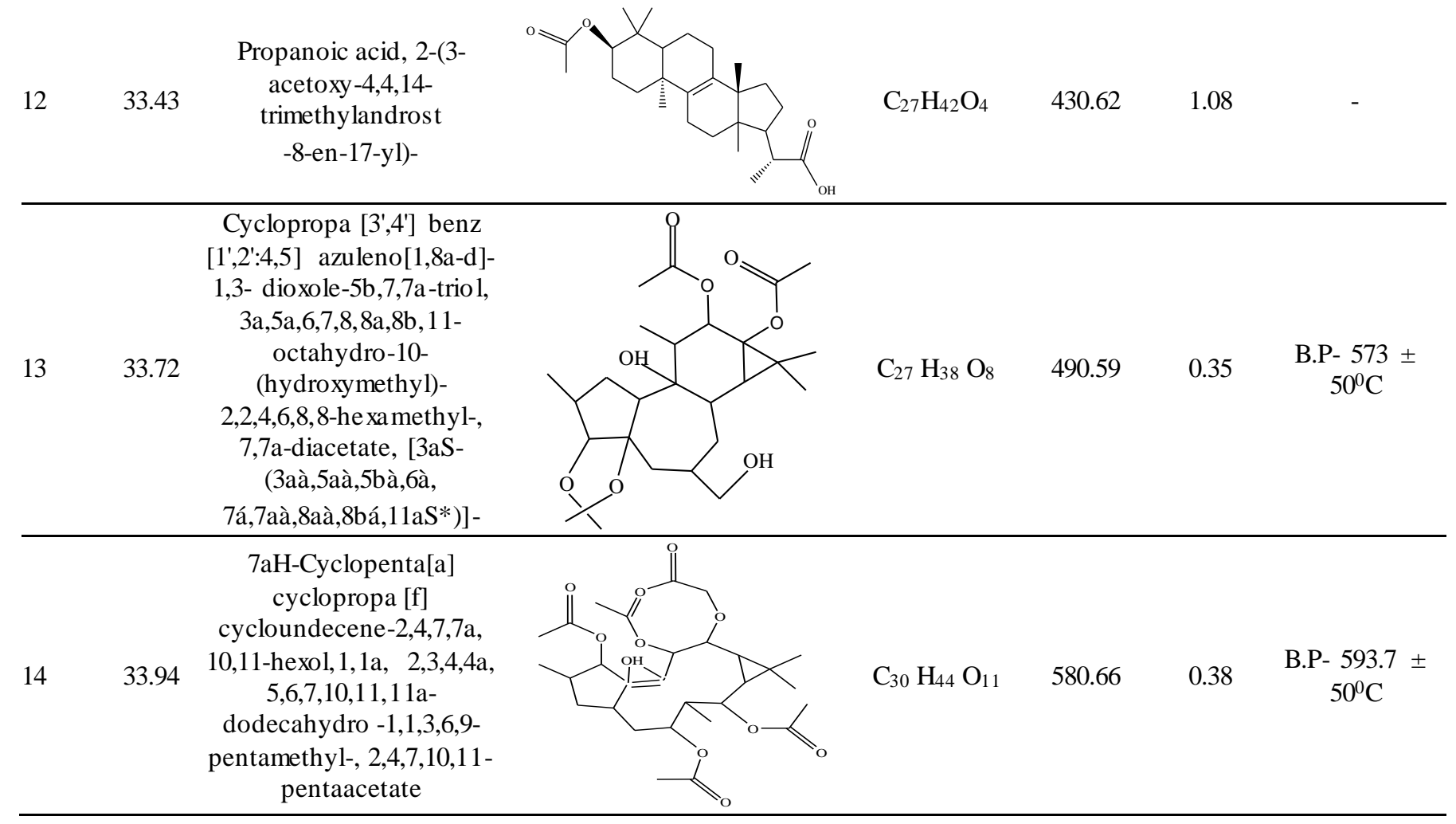

TABLE 6. Phytochemicals identified from GC-MS analysis of DACN extract

\begin{tabular}{|c|c|c|c|c|c|c|c|}
\hline Sl. No & RT & $\begin{array}{l}\text { Chemical compound of } \\
\text { Dry Areca Nut extract } \\
\text { (DACN) }\end{array}$ & Chemical Structure & $\begin{array}{l}\text { Molecular } \\
\text { formula }\end{array}$ & $\begin{array}{l}\text { Molecular } \\
\text { Weight }\end{array}$ & $\begin{array}{c}\% \text { Peak } \\
\text { area }\end{array}$ & $\begin{array}{l}\text { Melting Point } \\
\text { and Boiling } \\
\text { Point }\end{array}$ \\
\hline 1 & 17.35 & Tetradecanoic acid & & $\mathrm{C}_{14} \mathrm{H}_{28} \mathrm{O}_{2}$ & 228.37 & 11.78 & $\begin{array}{l}\text { M.P- } 58.5^{0} \mathrm{C} \\
\text { B.P- } 326.2^{0} \mathrm{C}\end{array}$ \\
\hline 2 & 21.81 & Squalene & & $\mathrm{C}_{30} \mathrm{H}_{50}$ & 410.72 & 2.22 & $\begin{array}{c}\text { M.P- }<-20^{\circ} \mathrm{C} \\
\text { B.P- } 284-285^{\circ} \mathrm{C}\end{array}$ \\
\hline 3 & 25.95 & Tetratriacontane & & $\mathrm{C}_{34} \mathrm{H}_{70}$ & 478.92 & 3.34 & $\begin{array}{c}\text { M.P- } 72.6^{0} \mathrm{C} \\
\text { B.P- } 483^{\circ} \mathrm{C}\end{array}$ \\
\hline 4 & 26.79 & $\begin{array}{c}\text { Benzoic acid, 3,5- } \\
\text { dicyclohexyl-4-hydroxy-, } \\
\text { methyl ester }\end{array}$ & & $\mathrm{C}_{20} \mathrm{H}_{28} \mathrm{O}_{3}$ & 316.43 & 15.13 & $\begin{array}{c}\text { B.P- } 381.1 \pm \\
42^{0} \mathrm{C}\end{array}$ \\
\hline 5 & 30.22 & $\begin{array}{c}\text { Bicyclo[5.3.0]decan-2- } \\
\text { one, 9- } \\
\text { (diphenylmethylene)- }\end{array}$ & & $\mathrm{C}_{23} \mathrm{H}_{24} \mathrm{O}$ & 316.44 & 11.64 & B.P-480.8 $\pm 14^{0} \mathrm{C}$ \\
\hline
\end{tabular}


In tender areca nut extract nine compounds were identified, out of that tetratetracontane $(4.56 \%)$, triacontane $(4.00 \%)$ and hexatriacontane $(8.66 \%)$ present in major amounts. Fourteen phytochemicals were identified in mature stage of areca nut out of that13-docosenamide, (Z)- (12.16\%), Bis (cis-13docosenamido) methane (7.24\%) and heptasiloxane,1, 1, 3, 3, $5,5,7,7,9,9,11,11,13,13$-tetradecamethyl- $(5.52 \%)$ present in major amount. Five chemical compounds were identified from Dry areca nut extract benzoicacid, 3,5dicyclohexyl-4-hydroxy, methylester (15.13\%), bicyclo [5.3.0] decan-2-one, 9-(diphenylmethylene)- (11.64\%) and Tetradecanoic acid(11.78\%) present in major amount. The percentage of each component is obtained from peak area in GC-MS. since it is said that the area under each peak is proportional to the concentration of that component in the original mixture [29-31].

Indolo [2,3-a] quinolizine -2-ethanol, 3-ethenyl1,2,3,4,6,7,12,12b-octahydro-9methoxy, (2R,3R,12bS)- and Octasiloxane,1, 1, 3, 3, 5, 5, 7, 7, 9, 9, 11, 11, 13, 13, 15, 15 hexadecamethyl- present in tender extract possess antidepressant and anti-microbial property [32,33]. Antimicrobial, antioxidant and anti-inflammatory properties are present in 13-Docosenamide, (Z)- compound [34]. Siloxane componds have antimicrobial and antifoaming activity [35]. Acetamide, N-[(7S)-5,6,7,9-tetrahydro1,2,3,10-tetrametho xy-9-o xobenzo[a]heptalen-7-yl]- also called Colchicine used in the treatment of Gout, familial meditarian fever used in prevention of microtube assembly [36,37]. Propanoic acid, 2-(3-acetoxy-4,4, 14trimethylandrost-8-en-17-yl)- contain antimicrobial and antitumor activity [38]. Tetradecanoic acid also called as Myristic acid is a long chain fatty acid they are used in the preparation of antiulcer medicines, soaps and perfumes [39]. Benzoic acid, 3,5-dicyclohexyl-4-hydroxy-, methyl ester contains Antifungal and Antibacterial activity [40]. Tetratriaconate has antibacterial and antifungal activity [41]. Squalene shows anticancer, antioxidant, drug carrier, hypocholestrolemic, detoxifying, skin hydrating and emollient and antitumor activities [42, 43].

\section{Thermogravimetric analysis}

Thermal analysis was performed on Tender areca nut extract, mature areca nut extracts and Dry areca nut extract, they differ in the chemical composition that was identified from GC-MS analysis. Thermal decomposition curve of samples can be described in five stages in case of TACN and six stages in case of MACN and DACN extracts as shown in the Figures 7 to 9, compound present in each decomposition stage is tabulated in Table 6. Such systems are typical for the material with plant origin, they are independent of dilution and hence they do not show sporadic oxidation and incomplete combustion, but rather they indicate discrete chemical reactions taking place throughout TGA analysis [44].

Thermal decomposition of TACN extract occurs at five stages. TG/DTG curve obtained in first stage is due to evaporation of water molecule and decomposition of compounds with lower boiling point, namely $\mathrm{C}_{16} \mathrm{H}_{50} \mathrm{O}_{7} \mathrm{Si}_{8}$ $\left(105^{0} \mathrm{C}\right), \mathrm{C}_{12} \mathrm{H}_{36} \mathrm{O}_{5} \mathrm{Si}_{6}\left(130^{\circ} \mathrm{C}\right)$. Some of the compounds with low melting point started to melt compounds such as $\mathrm{C}_{44} \mathrm{H}_{90}$ $\left(87-88^{0} \mathrm{C}\right), \quad \mathrm{C}_{30} \mathrm{H}_{62}\left(65.8^{0} \mathrm{C}\right), \quad \mathrm{C}_{36} \mathrm{H}_{74}\left(76.5^{\circ} \mathrm{C}\right)$. Plant extracts are reported to contain hemicellulose, cellulose and lignin [45].Thermal depolymerisation of hemicellulose and cleavage of glycosidic linkage of cellulose takes place at 220 $300^{\circ} \mathrm{C}$ [48]. Decomposition of chemicals identified from TACN extracts i.e. $\mathrm{C}_{36} \mathrm{H}_{74}\left(298.4^{0} \mathrm{C}\right)$ also occur at stage-3. Decomposition of cellulose (occurs in between $275^{\circ} \mathrm{C}$ $\left.400^{\circ} \mathrm{C}\right)[46,48]$ and $\mathrm{C}_{30} \mathrm{H}_{62}\left(449.7^{\circ} \mathrm{C}\right)$ occur at stage-4. Stage 5 is obtained due to decomposition reaction of high molecular weight and aromatic compounds. The compounds may be present are $\mathrm{C}_{20} \mathrm{H}_{36} \mathrm{~N}_{2} \mathrm{O}_{2}\left(508.6 \pm 50^{0} \mathrm{C}\right), \mathrm{C}_{27} \mathrm{H}_{52} \mathrm{O}_{4} \mathrm{Si}_{2}(500.6 \pm$ $\left.50^{\circ} \mathrm{C}\right), \mathrm{C}_{44} \mathrm{H}_{90}\left(548^{\circ} \mathrm{C}\right)$. Constant weight change is due to the change of the metal compounds as metal oxides that are present in trace amount. DTA curve indicate that the process involved throughout is exothermic reaction [47].

Decomposition process takes place at six stages in MACN and DACN. TG/ DTG curve present in stage-1 of MACN is due to evaporation of water molecule and decomposition of compounds with lower melting and boiling points. Compound present are $\mathrm{C}_{16} \mathrm{H}_{50} \mathrm{O}_{7} \mathrm{Si}_{8}\left(105^{\circ} \mathrm{C}\right), \mathrm{C}_{12} \mathrm{H}_{36} \mathrm{O}_{5} \mathrm{Si}_{6}\left(130^{\circ} \mathrm{C}\right)$, $\mathrm{C}_{14} \mathrm{H}_{44} \mathrm{O}_{6} \mathrm{Si}_{7}\left(108-128^{0} \mathrm{C}\right), \mathrm{C}_{22} \mathrm{H}_{43} \mathrm{NO}\left(75-80^{\circ} \mathrm{C}\right)$. Compounds such as $\mathrm{C}_{8} \mathrm{H}_{24} \mathrm{O}_{4} \mathrm{Si}_{4} \quad\left(175^{\circ} \mathrm{C}\right), \quad \mathrm{C}_{10} \mathrm{H}_{16} \quad\left(166.5-167.0^{0} \mathrm{C}\right)$,

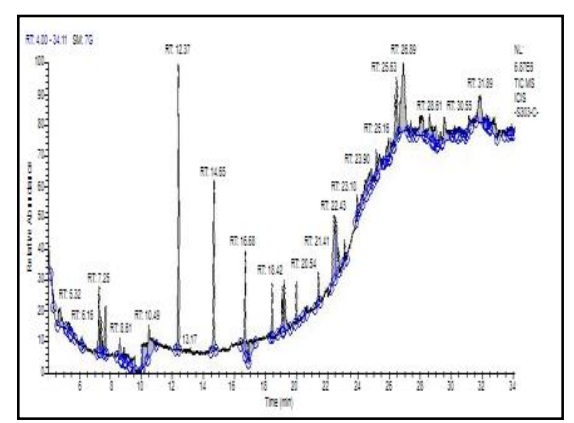

Figure 5. GC Chromatogram of TACN extracts

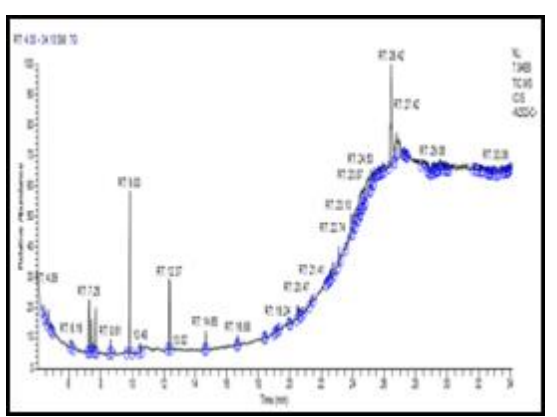

Figure 6. GC Chromatogram of MACN extracts

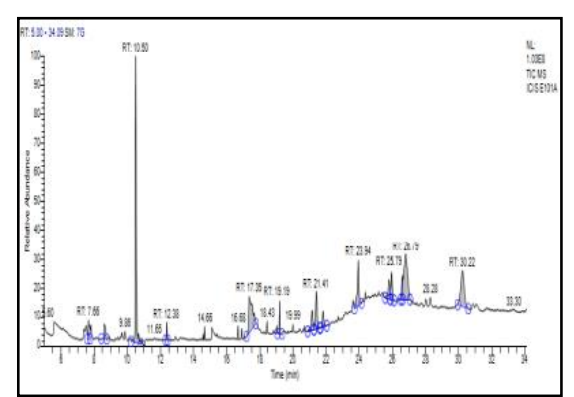

Figure 7. GC Chromatogram of DACN extracts 


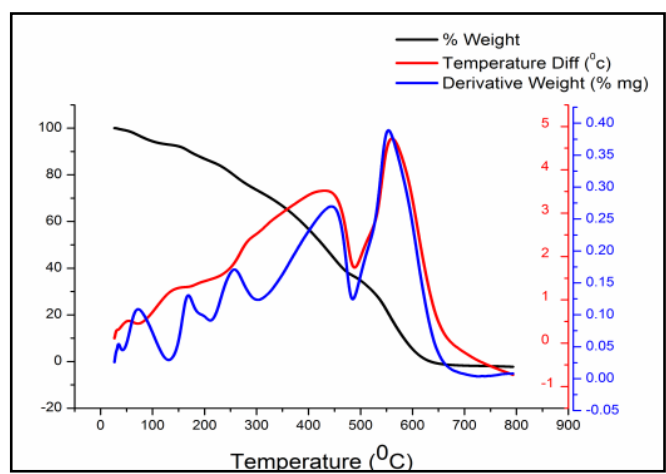

Figure 8. TGA graph of TACN extract

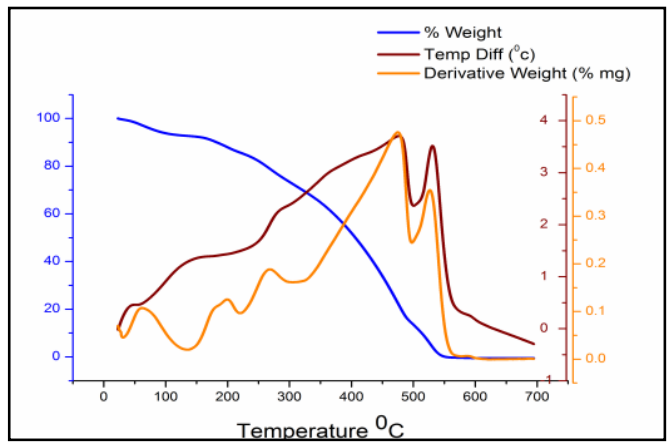

Figure 9. TGA graph of MACN extract

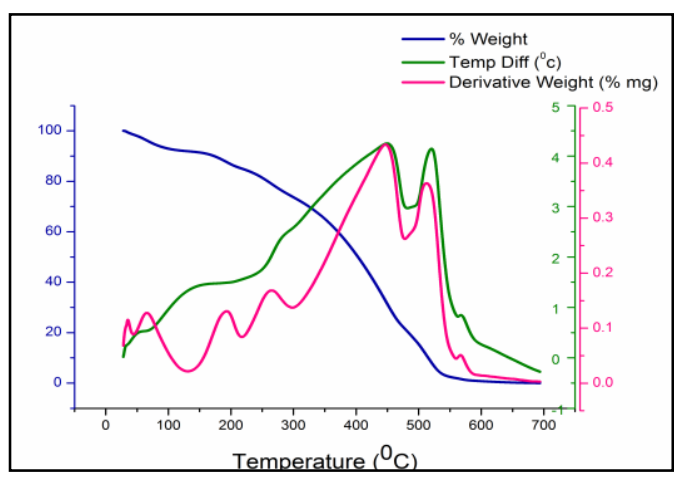

Figure 10. TGA graph of DACN extract

$\mathrm{C}_{22} \mathrm{H}_{25} \mathrm{NO}_{6}\left(142-150^{\circ} \mathrm{C}\right)$ are decompose at stage-2. Plant extracts are reported to contain hemicellulose, cellulose and lignin [45].Thermal depolymerisation of hemicellulose and cleavage of glycosidic linkage of cellulose takes place at 220 $300^{\circ} \mathrm{C}$ [48]. Stage-4 is due to the decomposition of chemical compound $\mathrm{C}_{22} \mathrm{H}_{43} \mathrm{NO}\left(474 \pm 14^{\circ} \mathrm{C}\right)$ and cellulose. Compounds with higher boiling temperature such as $\mathrm{C}_{20} \mathrm{H}_{13} \mathrm{~N}_{5} \mathrm{O}_{2}(662.5 \pm$ $\left.65^{\circ} \mathrm{C}\right), \mathrm{C}_{27} \mathrm{H}_{36} \mathrm{O}_{8}\left(650.3 \pm 55^{\circ} \mathrm{C}\right), \mathrm{C}_{28} \mathrm{H}_{37} \mathrm{ClO}_{11}\left(641.3 \pm 55^{\circ} \mathrm{C}\right)$, $\mathrm{C}_{27} \mathrm{H}_{38} \mathrm{O}_{8}\left(573 \pm 50^{\circ} \mathrm{C}\right)$ and $\mathrm{C}_{30} \mathrm{H}_{44} \mathrm{O}_{11}\left(593.7 \pm 50^{\circ} \mathrm{C}\right)$ decompose in stage-6. Constant weight change is due to the change of the metal compounds as metal oxides that are present in trace amount. DTA curve indicate that the process involved throughout is exothermic reaction [47].

TG/DTG curve present in stage-1 of DACN extract indicates the decomposition of water molecule and decomposition of the chemical compounds with low molecular weight. Chemical present in this stage are $\mathrm{C}_{14} \mathrm{H}_{28}$ $\mathrm{O}_{2}\left(58.5^{\circ} \mathrm{C}\right), \mathrm{C}_{34} \mathrm{H}_{7}\left(72.6^{\circ} \mathrm{C}\right)$. Plant extracts are reported to contain hemicellulose, cellulose and lignin [45]. Thermal depolymerisation of hemicellulose and cleavage of glycosidic linkage of cellulose takes place at $220-300^{\circ} \mathrm{C}$ [48]. Decomposition of compound $\mathrm{C}_{30} \mathrm{H}_{50}\left(284-285^{\circ} \mathrm{C}\right)$ also occur at stage-3. Decomposition of cellulose and phytochemicals such as $\mathrm{C}_{14} \mathrm{H}_{28} \mathrm{O}_{2}\left(326.2^{\circ} \mathrm{C}\right), \mathrm{C}_{20} \mathrm{H}_{28} \mathrm{O}_{3}\left(381.1 \pm 42^{\circ} \mathrm{C}\right)$ occur at stage-4. Decomposition of aromatic and compounds with high molecular weight occur at stage-5. The compounds present at this stage are $\mathrm{C}_{34} \mathrm{H}_{70}\left(483^{\circ} \mathrm{C}\right), \mathrm{C}_{23} \mathrm{H}_{24} \mathrm{O}(480.8 \pm$ $14^{\circ} \mathrm{C}$ ). Constant weight change is due to the changes of the metal compounds as metal oxides that are present in trace amount. DTA curve indicate that the process involved throughout is exothermic reaction [47].

\section{CONCLUSION}

In the present study areca nut extract at different stages were extracted and characterized by AAS, XRD, FTIR, GC-MS and TGA. Spectroscopic techniques showed the presence of $\mathrm{OH},-\mathrm{NH},-\mathrm{COOH}$ etc as a functional groups. Essencial trace elements are also observed from AAS analysis. Different types of phytochemicals were identified at the different stages of areca nut extract, all the identified chemical compounds were further confirmed by TGA analysis. All the bioactive compounds are having very good medicinal properties.

\section{ACKNOWLEDGEMENT}

The authors are thankful to the coordinator DST-FIST program, USIC, DST-PURSE laboratory, Mangalore university and CIL Punjab university for providing instrumentation facilities.

\section{REFFERENCE}

1. Craig R Elevitch, 2006; "Traditional Trees of Pacific Islands: Their Culture, Environmentand USA" Permanent Agriculture Resources (PAR) publisher, USA; pp - 69-84.

2. Preetee Jaiswal, Pradeep Kumar, V.K.Singh and D.K. Singh, 2011; "Areca catechu L. A Valuable Herbal Medicine Against Different Health Problems" Research Journal of Medicinal Plant; 5(2); 145-152.

3. Bhandare A, Kshirsagar A, Vyawahare N, Hadambar A, Thorve S. 2010; Potential analgesic, anti-inflammatory and antioxidant activities of hydroalcoholic extract of Areca catechu L. nut. Food and Chemical Toxicology 48(12):3412-3417.

4. Anthikat RRN, Michael A, Vageesh S, Balamurugan R, Ignacimuthu S. 2014 "The effect of Areca catechu L. extract on streptozotocin induced hyperglycemia in Wistar rats". International Journal of Pharma and Bio Science; 5(4):316 - 21.

5. Park YB, Jeon SM, Byun SJ, Kim HS, Choi MS. 2002; "Absorption of intestinal free cholesterol is lowered by supplementation of Areca catechu L. extract in rats". Life Sciences, 70(16):1849-59. 
6. Jiang JH, Jung SY, Kim YC, Shin SR, Yu ST, Park H. 2009;"Antimalarial effects of Areca catechu L". Korean J. Oriental Physiology and Pathology; 23(2): 494-8.

7. Lee KK, Choi JD. 1999; “ The effects of Areca catechu $\mathrm{L}$ extract on anti-aging". International J Cosmetic Science.;21(4), 285-95.

8. Joshi M, Gaonkar K,Mangoankar S, Satarkar S. 2012; "Pharmacological investigation of Areca catechu extract forevaluation of learning, memory and behaviour in rats". International Current Pharmaceutical Journal;1(6):128-132.

9. Bhandare A, Kshirsagar A, Vyawahare N, Sharma P, Mohite R, 2011; "Evaluation of anti-migraine potential of Areca catechu to prevent nitroglycerin-induced delayed inflammation in rat meninges: possible involvement of NOS inhibition". Journal of Ethnopharmacology; 136(1):267-70.

10. Inokuchi J, Okabe H, Yamauchi T, Nagamatsu A,Nonaka G, et al. 1986; "Antihypertensive substance in seeds of Areca catechu L". Life Sciences; 38(15): 1375-82.

11. Dar A, Khatoon S, Rahman G, Rahman AU. 1997; “Antidepressant activities of Areca catechu fruit extract". Phytomedicine; 4(1):41-5.

12. Lee JH, Chang SH, Park YS, Hes E, Lee HY, et al. 2004; "In-vitro and in-vivo anti-allergic actions of Areca semen". J Pharmacy and Pharmacology;56(7):927-33.

13. KeshavaBhat S, Mythri S, Ashwin D. 2016; "Anthelmintic property of areca nut (Areca catechu L.): A review". Indian Journal of Areca nut Spices and Medicinal Plants; 18(2), 20-7.

14. Sazwi NN, Nalina T, Abdul Rahim ZH. 2013; "Antioxidant and cytoprotective activities of Piper betle, Areca catechu, Uncarria gambir and betel quid with and without calcium hydroxide". BMC Complementary and Alternative Medicine; 13:351.

15. Keshava Bhat Sarpangala, Mythri Sarpangala, Ashwini Devasya, 2017; "Antimicrobial Properties of Areca nut, Areca catechu L; A Review" International. Journal of .Research in Ayurveda and Pharmacy; 8(3); 8-12.

16. Kumari HL, Sirsi M, Bhargava MK. 1974; "Inhibitory activity of Areca catechu on the development of mouse skin tumours induced by the chemical carcinogen 3.4, benzpyrene". J Plantation Crop; 2(1): 23-29.

17. Muyiwa Turoti, C. E. Gimba, and S. S. Achi. 2010. "Environmental degradation of surface coatings: I. stabilization of green poly (glycerol-phthalate) based alkyd coatings with some dibutyltin dicarboxylates during outdoor exposure." Toxicological \& Environmental Chemistry 92(5): 885-892.

18. Petra Marschner, 2012; “Marschner's Mineral Nutrition of Higher Plants" Academic Press; California; $3^{\text {rd }}$ edition; pp- 135-250.

19. Michael.I.Goran; Luc Tappy; Kim-Ann Le; 2014; "Dietary Sugars and Health", CRC Press, Newyork; pp62.
20. John Griffith Vaughan; 2003; "The Oxford Book of Health Food : A Comprehensive Guide to Natural Remedies", Oxford University Press, Newyork; pp-61.

21. Marion Eugene Ensmiger; Audrey H. Ensminger, 1993;"Food and Nutrition Encyclopedia" CRC Press Newyork; 2nd edition volume 1; pp- 719.

22. Mark Crocker, 2010; "Thermochemical Conservation of Biomass of Liquid Fuels and Chemicals", Royal Society of Chemistry, Cambridge; pp-347-348.

23. L. Segal.J; J. Creely; A.E. Martin; Jr.C. M. Conrad; 1959; "An Empirical Method for Estimating the Degree of Crystallinity of Native Cellulose Using the X-ray Diffractometer" Textile Research Journal; 29(10); 789794.

24. Tomy. J. Gutierrez; 2018; "Polymer for Food Applications" Springer, Switzerland; pp- 538.

25. Fem D.S. Marquis; 2017; "Proceedings of the $8^{\text {th }}$ Pacific Rim International Conference on Advanced Materials and Processing (PRICM-8)- The Minerals, Metals and Materials series" Springer, Switzerland; pp- 3243.

26. Cury Suryanarayana; 2004; "Mechanical Alloying and Milling" CRC Press, Newyork; pp-110-113.

27. Dewan S.K, 2010; "Organic Spectroscopy: (NMR, IR, Mass and UV)" CBS Publisher and Distributor Pvt. Ltd; first edition; pp- 400-463.

28. Deepa Santhanakrishnan; Supriya N. Shankar; Bangaru Chandrasekaran, 2014; "Studies on Photochemistry, Spectroscopic Characterization and Anti-bacterial Efficacy of Salicornia brachiata" International journal of Pharmacy and Pharmaceutical Sciences; 6(6); 430-432.

29. Galen W. Ewing; 1985; "Instrumental Method of Chemical Analysis", Mc Graw- Hill Book Co, Singapore; pp- 367-369.

30. Donald T Sawyer; William R. Heinman; Janice M. Beebe; 1984; “Chemistry Equipment's for Instrumental Methods" John Wiley and Sons, Newyork; pp- 327.

31. Dr. Supriya S. Mahajan; 2010; "Instrumental Method of Analysis", Prakashan Private Limited, Mumbai; pp-235240.

32. Robert B Raffa, 2014; "Kartom and Mitragynines; The Chemistry and Pharmacology of Opioids from NonOpinum Source" CRC press New york; pp- 197.

33. Ojochenemi. E Yakubu, Olawale otitoju and Joshua onwuka, 2017; “ Gass chromatography- Mass spectroscopy (GC-MS) analysis of Aqueous Extract of Daniellia Oliveri Stem Bark" Pharmaceutical Analytical Acta; 8(11).

34. Sirigiri chandrakala and Kandru Ammani, 2017; "GCMS analysis of Biologically active compounds in Canthium parviflorum Lam. Leaf and callus extract" Internatinal jornal of Chem Tech research; 10(6); pp1038-1058.

35. Sanjay K Sharma; 2011; “ Green Corrosion Chemistry and Engineering Opportunities and Challenges" John Willey and sons, Germany; pp-96. 
36. Lawrence A Schachner, Ronald C Hansen, 2011; “ Pediatric Dermatology E-book" $4^{\text {th }}$ edition; Elsevier Health Science publication, New york; pp-177.

37. David S.Seigler, 1998; "Plant secondary Metabolism" Springer Science and Business Media, New york; pp617-621.

38. Mohamad Jawad Kadham; Ghaidaa Jihadi Mohamed and Imad Hadi Hameed, 2016; "Invitro Antibacterial, Antifungal and Phytochemical Analysis of Methanolic extract of fruit Cassia fistula" Oriental Journal of chemistry; 32(13); pp- 1329-1346.

39. Eula Bingham, Barbara Cohrssen; 2012; "Patty's Toxicology" John Wiley and sons, New Jersey; Volume 6; pp-584.

40. Chukwunonye M; Ojinnaka kelechi I and Marycolatte $\mathrm{N}$ Ezediokpu; 2015; "The Chemical Constituents and Bioactivity of seed (Fruit) Extract of Buchholzia Coriacea Engler (capparaceae)" Journal of applied science and Environment; 19(4); pp-795-801.

41. Mustaph N.Abubakar and Runner R.T.Majinda; 2016 "GC-MS Analysis and Preliminary Antimicrobial Activity of Albizia adianthifolia (Schumach) and Peterocarpus angolensis (DC)" Journal of Medicine 3 (3).

42. Victor R Preedy; Ronald Ross Watson, 2014; "The Mediterranean Diet: An Evidence- Based Approach" Academic Press, London; pp-281-289.
43. Egui zhu; Sabo Sambath, 2012; "Information Technology and Agricultural Engineering Volume 134 of Advances in Intelligent and Soft Computing" Springer Science and Business Media, New york; pp-650.

44. Oskars Purmalis; Dmitrijs Porsnovs; Maris Klavins, 2011; "Differential Thermal analysis of Peat and Peat Humic Acids" Scientific Journal of Riga Technical University Materials Science and Applied Chemistry; Volume 24; pp- 89-94.

45. Ashok Pandey, 2008; "Hand book of Plant- Based Biofuels" CRC Press, Boca Raton; pp-122.

46. A.V. Bridgwater, 2013; "Advances in Thermochemical Biomass Conversion" Springer Science and Business Media, Dordrecht; pp- 774.

47. Darrel.D.Nicholas, 1982; "Wood Deterioration and its prevention by Preservative Treatments: Degradation and Protection of Woods" Syracuse university Press, New york; pp- 310.

48. Jitendra K. Pandey; Hitoshi Takagi; Antanio Nario Nakagaito; Hyun-Joong Kim, 2014; "Hand Book of Polymer Nano composites, Processing, Performance and Applications: Volume C: Polymer Nano composites of Cellulose Nano particles", Springer, Newyork; pp-74-77. 